\title{
Seminal Plasma: Effect on Motility, Membrane Functionality, and Spermatic Chromatin Dispersion of Equine Sperm Treated with $\mathrm{N}$-acetyl-L-cysteine at $5^{\circ} \mathrm{C}$
}

\author{
Murilo Farias Rodrigues', Janislene Mach Trentin', Laurence Boligon de Araujo², \\ Luiz Augusto Machado Centeno², Ricardo Olimpio Schenatto' ${ }^{2}$, Gilson Antonio Pessoa', \\ Adriana Pires Neves ${ }^{3} \&$ Mara lolanda Batistella Rubin ${ }^{4}$
}

\begin{abstract}
Background: N-acetyl-L-cysteine (NAC) is a low molecular weight thiol studied as an antioxidant for stallion semen preservation without changes on sperm viability. Equine seminal plasma is rich in sulfur proteins (cysteine residues) named CRISPS, which, when combined with sulfur-containing antioxidants, can enhance the appearance of DNA lesions. The aim of this study was to assess and compare the effect of different concentrations of NAC by evaluating motility, membrane function and sperm chromatin integrity of equine semen cooled at $5^{\circ} \mathrm{C}$ in $50 \%$ of seminal plasma.

Materials, Methods \& Results: Nine ejaculates from 9 stallions were divided into 4 aliquots, diluted and divided in nonsupplemented skim milk group $(0.0 \mathrm{mM})$, or supplemented with 5.0, 2.5 and $0.5 \mathrm{mM} \mathrm{NAC}$. Evaluations were made at $0 \mathrm{~h}$, $24 \mathrm{~h}$ and $48 \mathrm{~h}$ of cooling, except for motility which was evaluated only up to $24 \mathrm{~h}$. The $0.5(59.7 \mu \mathrm{M} 2)$ and $5.0 \mathrm{mM}$ NAC $(55.5 \mu \mathrm{M} 2)$ groups showed similar areas of sperm chromatin dispersion among all groups. However, the area of chromatin dispersion between the non-supplemented group was higher $=65.3 \mu \mathrm{M}_{2}$ than the group supplemented with $2.5 \mathrm{mM}$. The percentage of cells with a functional plasma membrane was similar between supplemented and non-supplemented $(0.0$ $\mathrm{mM})$ groups, but higher $(P<0.05)$ in the $0.5 \mathrm{mM} \mathrm{NAC} \mathrm{(39.7} \mathrm{and} \mathrm{39.8 \% ,} \mathrm{respectively)} \mathrm{than} \mathrm{that} \mathrm{of} 2.5 \mathrm{mM}(34.5 \%)$ and $5.0 \mathrm{mM}(34.2 \%)$ concentrations. Progressive motility was similar among all groups supplemented with NAC. The 0.5 mM NAC group showed 35.2\% motile cells while the non-supplemented group exhibited $36.2 \%$. Although 50\% seminal plasma was used, NAC did not affect sperm chromatin integrity.

Discussion: Seminal plasma interfered more in the results of different concentrations of NAC. This statement is proven by the motility analysis where all NAC concentrations showed similar results. Plasma percentage higher than $20 \%$ in diluted semen causes deleterious effects on sperm, such as decreased motility and fertilizing capacity. The membrane analysis in our study was compromised because NAC (2.5 to $5.0 \mathrm{mM}$ ) showed high osmolarity. As this was not adjusted, it affected the result. The $2.5 \mathrm{mM}$ NAC group showed a lower area of sperm chromatin dispersion than none-treated sperm, although showing similar results to the other treatments. In a study with semen of Mangalarga Marchador stallions, the $2.5 \mathrm{mM}$ of NAC was able to protect sperm membrane integrity. However, in another study, where semen was kept cooled between 5 and $15^{\circ} \mathrm{C}$, no change was observed on sperm quality over different concentrations of NAC. This reinforces that $2.5 \mathrm{mM}$ of NAC provides adequate protection to semen exposed to harmful conditions. The high percentage of plasma associated with this sulfur antioxidant did not compromise DNA integrity, as NAC concentration used was 100 times less than the concentration needed to induce DNA lesions.
\end{abstract}

Keywords: N-acetyl-L-cysteine, equine, semen, cooling, fragmentation. 


\section{INTRODUCTION}

The high content of polyunsaturated fatty acids and low concentration of antioxidant enzymes in the small cytoplasm of spermatozoa makes it susceptible to reactive oxygen species (ROS) [20]. ROS are free radicals capable of dismantling the components present in the cytoplasm, plasma membrane and cellular DNA.

The addition of antioxidants in semen extenders has been widely studied for preventing sperm impaction. $\mathrm{N}$-acetyl cysteine (NAC) at concentration of 2.5 $\mathrm{mM}$ achieved satisfactory results when used on dog [19], swine [27], and frozen / thawed equine semen [9]. However, the same antioxidant might injure DNA of human sperm [12], and it did not increase sperm quality of equine semen cooled at $15^{\circ} \mathrm{C}$ and $5^{\circ} \mathrm{C}$ [23]. The variable results observed in horses may be due to the preservation method and amount of seminal plasma. It is well known that horse seminal plasma is rich in sulfur proteins, mainly composed of cysteine residues [10] and that low molecular weight thiols, such as $\beta$-mercaptoethanol and NAC are able to break the protamine bridges in chromatin, thus exposing the DNA [5].

Although DNA exposure to these thiols requires concentrations 100 times higher than the one used in semen, prolonged exposure associated with a high percentage of seminal plasma may intensify injury of refrigerated semen. Considering that the effect of different concentrations of $\mathrm{N}$-acetyl-L-cysteine on pony semen are not well known, this study evaluated the effect of NAC on motility, membrane function and DNA damage of semen containing $50 \%$ of seminal plasma kept cooled at $5^{\circ} \mathrm{C}$.

\section{MATERIALS AND METHODS}

\section{Local and animal management}

This study was conducted from September to December (spring-summer in the southern hemisphere) 2012 at the Laboratório de Embriologia Animal of Universidade Federal de Santa Maria. To perform the experiment, 9 pony stallions of the Brazilian breed, 9 to 13 years old, were kept on native pasture, supplemented with oat plus perennial Bermuda Tifton 85 (Cynodon spp.) grass hay. All handling procedures in this trial followed general guidelines for animal welfare.

\section{Semen collection}

In order to afford depletion of gonadal reserves before starting the experiment, the animals underwent semen collection and evaluation 3 times a week for
4 weeks. Then 18 semen collections [16] were made from 9 ponies using a Hannover model artificial vagina [11]. These collections were made 3 times a week, in 3 animals at each time. Sampling was performed according to a standardized protocol used at the laboratory.

\section{Semen analysis}

The macroscopic analysis (volume, gross appearance and color) was finished within 10 min after semen collection. The ejaculates were diluted 1:2 (semen:extender), resulting in $50 \%$ of seminal plasma. The extender consisted of $2.4 \mathrm{~g}$ of skim milk powder, $14.42 \mathrm{mM}$ of sodium bicarbonate ${ }^{1}$ and $272 \mathrm{mM}$ of glucose1 [14] and NAC1 (NAC supplemented groups) or not (non-supplemented). NAC antioxidant addition was performed using 1:2 dilution, resulting in final concentrations of $0.5 ; 2.5$ and $5.0 \mathrm{mM}$.

\section{Analysis of sperm motility and membrane function}

Sperm motility was assessed under phase contrast microscopy (Olympus BX41- Japan) according to the protocol [26] followed at the laboratory. The percentage of sperm with progressive motility (MP) was assessed immediately after dilution $(0 \mathrm{~h})$ and after cooling to $5^{\circ} \mathrm{C}$ at $24 \mathrm{~h}$ and $48 \mathrm{~h}$.

Sperm membrane function was evaluated by using two parts of distilled deionized preheated water to one part of semen to reach an osmolarity around 100 mOsm after $10 \mathrm{~min}$ of exposure [16]. The evaluation was performed under phase contrast microscopy using 400X magnification, and two hundred whole cells [21] were assessed.

\section{Fragmentation analysis}

Storage and preparation of slides with diluted ejaculates at room temperature $(0 \mathrm{~h})$ and cooled at 24 $\mathrm{h}$ and $48 \mathrm{~h}$ were performed as recommended by the Halomax Kit - Equus caballus ${ }^{2}$. Samples were analyzed on a digital inverted microscope with fluorescence (Leica DMI 4000 B, Germany) and 1000 X magnification under oil immersion. A bank of 20 images of the sperm samples of each pony (all groups) at each cooling period was stored for the measurement of cluster areas of sperm chromatin in software (ImageJ 1.46). The software was calibrated using a graduated scale printed on the microscope camera images (Figure 1).

\section{Maintenance and semen cooling rate}

Diluted semen samples were first kept at room temperature $\left(22^{\circ} \mathrm{C} \pm 2\right)$ in closed $50 \mathrm{~mL}$ tubes (Corn- 
ing®) for 45 to $60 \mathrm{~min}$. Thereafter, the tubes were maintained horizontally in a refrigerator at $5^{\circ} \mathrm{C} \pm 1.6$ for $24 \mathrm{~h}$ or $48 \mathrm{~h}$ (Figure 2). The cooling rate ranged from 0.6 to $0.8^{\circ} \mathrm{C} / \mathrm{min}$.

\section{Statistical analysis}

The samples that were collected at $0 \mathrm{~h}, 24 \mathrm{~h}$ and $48 \mathrm{~h}$ of each treatment were analyzed by mixed models
(Proc Mixed). The stallion effect was determined as blocks. The comparison of means was performed by Tukey-Kramer test at 5\% significance level. Progressive motility was transformed into square root because it did not follow a normal distribution, thus providing for the use of these parametric tests. The SAS® software (version 9.2, SAS Institute Inc., Cary, NC, USA) was used for all analyses.

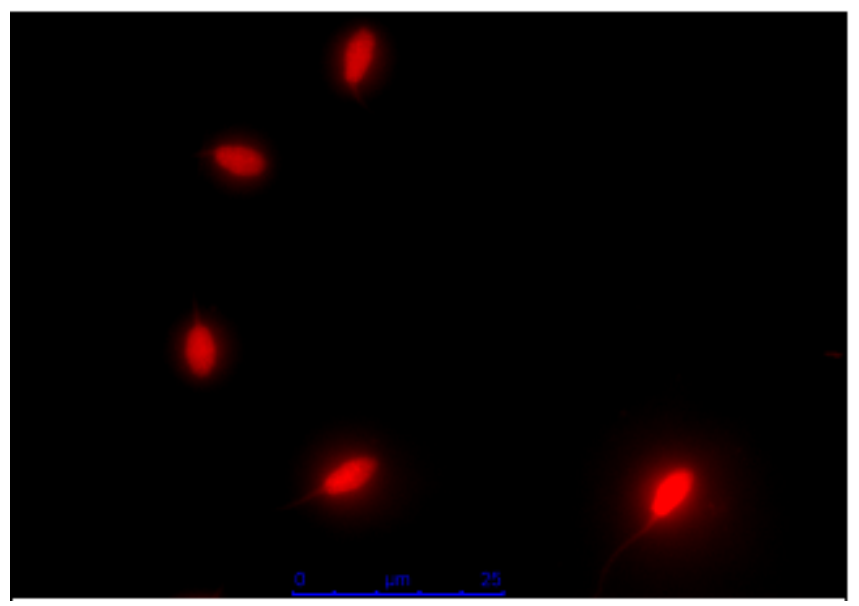

Figure 1. Dispersion test of equine sperm chromatin stained with propidium iodide (Halomax ${ }^{\circledR}$ Kit - Equus caballus Madrid / Spain.). The larger the halo indicates greater dispersion of chromatin (Personal Archive. MF Rodrigues, 2012).

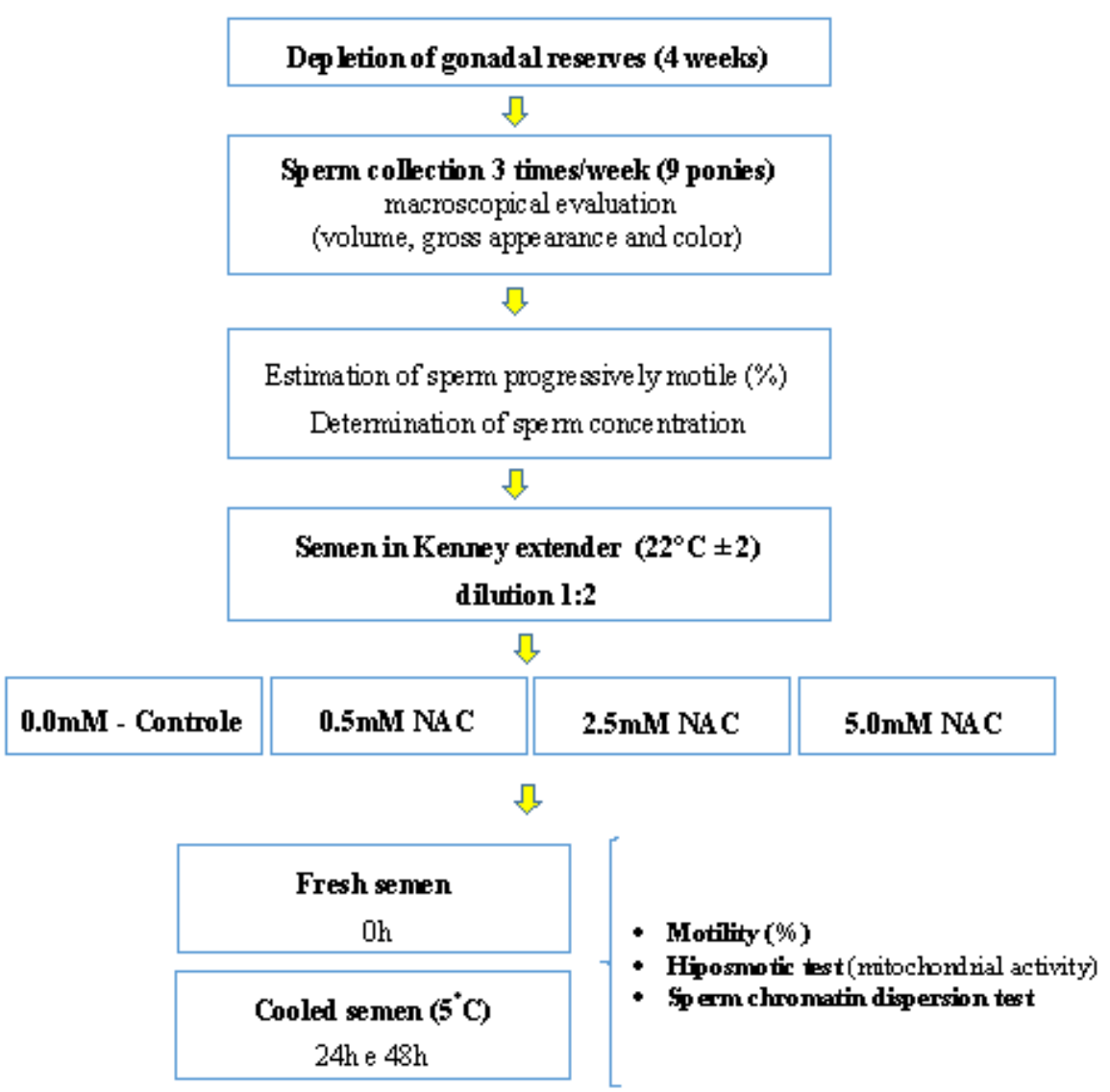

Figure 2. Experimental design of the procedures performed with the nine Brazilian ponies ejaculate. 


\section{RESULTS}

There was no interaction $(P>0.05)$ between the concentrations of NAC and cooling periods in any of the evaluated sperm variables. The dispersion test of sperm chromatin showed a significant increase $(P<0.05)$ in the area of fragmentation halo between $0 \mathrm{~h}$ and $24 \mathrm{~h}$ (Table 1), but was similar between $24 \mathrm{~h}$ and $48 \mathrm{~h}$ of cooling. The hypoosmotic test showed that the percentage of functional spermatozoa decreased $(P<0.05)$ at each assessed time. However, in this test the treatment without NAC and $0.5 \mathrm{mM}$ NAC showed a higher percentage of cells with functional membrane than NAC treatments 2.5 and $5.0 \mathrm{mM}$.
Progressive motility was lower $(P<0.05)$ at $24 \mathrm{~h}$ compared to time zero (Table 1 ). Average motility was $4.0 \%$ at $48 \mathrm{~h}$ and was not analyzed because of the large number of samples with zero value.

NAC concentrations of 0.5 and $5.0 \mathrm{mM}$ showed similar dispersion area of the sperm chromatin (Table 1). However, the area of chromatin dispersion of semen without NAC was higher than the one with $2.5 \mathrm{mM}$ NAC. The percentage of spermatozoa with functional cell membrane was similar between the group without NAC and the group treated with $0.5 \mathrm{mM}$ NAC (Table $1)$, although both were higher $(P<0.05)$ than NAC 2.5 $\mathrm{mM}$ and $5.0 \mathrm{mM}$. Progressive motility was not affected $(P>0.05)$ by the concentration of NAC (Table 1$)$.

Table 1. Dispersion area of sperm chromatin, membrane motility and functionality in accordance with different concentrations of $\mathrm{N}$-Acetyl-L-Cysteine (NAC) for equine sperm cooled to $5^{\circ} \mathrm{C}$ for different periods.

NAC concentrations

\begin{tabular}{cccccc}
\hline Period & $0.0 \mathrm{mM}$ & $0.5 \mathrm{mM}$ & $2.5 \mathrm{mM}$ & $5 \mathrm{mM}$ & Mean \\
\hline \multicolumn{5}{c}{ Sperm chromatin dispersion $\left(\mu \mathrm{m}^{2}\right)$} \\
\hline 24 & $76.1 \pm 10.1$ & $47.6 \pm 7.8$ & $41.7 \pm 5.8$ & $42.8 \pm 4.4$ & $44.5 \pm 7.4^{\mathrm{a}}$ \\
48 & $73.6 \pm 14.2$ & $67.8 \pm 20.4$ & $57.4 \pm 10.5$ & $63.4 \pm 12.6$ & $65.6 \pm 15.4^{\mathrm{b}}$ \\
\hline Mean & $65.3 \pm 21.3^{\mathrm{a}}$ & $59.7 \pm 17.6^{\mathrm{ab}}$ & $52.8 \pm 15.7^{\mathrm{b}}$ & $55.5 \pm 15.0^{\mathrm{ab}}$ & \\
\hline \multicolumn{5}{c}{ Membrane functionality $(\%)=$ Hyposmotic test } \\
\hline 0 & $55.9 \pm 9.4$ & $57.7 \pm 9.4$ & $53.2 \pm 9.5$ & $54.8 \pm 10.0$ & $55.4 \pm 9.3^{\mathrm{a}}$ \\
\hline 48 & $39.3 \pm 8.5$ & $36.3 \pm 11.1$ & $31.1 \pm 8.9$ & $28.3 \pm 10.2$ & $33.8 \pm 10.3^{\mathrm{b}}$ \\
\hline Mean & $23.9 \pm 7.5$ & $25.3 \pm 8.6$ & $19.2 \pm 6.8$ & $19.6 \pm 7.3$ & $22.0 \pm 7.7^{\mathrm{c}}$ \\
\hline \multicolumn{7}{c}{$39.7 \pm 15.7^{\mathrm{a}}$} & $39.8 \pm 16.6^{\mathrm{a}}$ & $34.5 \pm 16.5^{\mathrm{b}}$ & $34.2 \pm 17.8^{\mathrm{b}}$ & \\
\hline 0 & $51.9 \pm 7.1$ & $51.1 \pm 7.6$ & $50.6 \pm 7.7$ & $50.5 \pm 7.8$ & $51.0 \pm 7.2^{\mathrm{a}}$ \\
\hline 24 & $20.5 \pm 8.4$ & $19.2 \pm 8.7$ & $17.4 \pm 7.9$ & $15.2 \pm 5.8$ & $18.1 \pm 7.7^{\mathrm{b}}$ \\
\hline Mean & $36.2 \pm 17.8$ & $35.2 \pm 18.3$ & $34.0 \pm 18.7$ & $32.8 \pm 19.3$ & \\
\hline
\end{tabular}

abcDifferent letters in the columns and lines indicate differences between the evaluation periods and between the NAC concentration, respectively $(P<0.05)$. *The $48 \mathrm{~h}$ period of progressive motility assessment was removed from the analysis because presented most results equal to zero.

\section{DISCUSSION}

Seminal plasma serves as a transport and protection of sperm at the sperm tract and uterine environment, responsible for energy supply and conservation, helping $\mathrm{pH}$ balance, osmolarity and intrauterine immune modulation. In our research, we observed that $50 \%$ of plasma interfered more on results than the different concentrations of NAC on cooling, regardless of the evaluation method. Motility analysis shows that all treatments had similar results and that, within $48 \mathrm{~h}$ of cooling, plasma harmed the sample analysis by the deleterious effect caused. It is known that percentages higher than $20 \%$ of seminal plasma in diluted semen causes deleterious effects on sperm, such as decrease 
in motility and fertilizing capacity [14]. Studies have shown that in order to minimize the negative impact of seminal plasma on the storage of cooled semen, its volume should range from 5 to $20 \%$ [13], or a dilution of 25 million sperm/ $\mathrm{mL}$ [26] should be used.

The hypoosmotic test showed that 2.5 and 5.0 mM NAC compromised membrane function more than $0.5 \mathrm{mM}$ NAC and the group without NAC $(0.0$ $\mathrm{mM})$. In this study, all treatments had the same plasma percentage. We believe that the higher concentrations of NAC increased osmolality. As osmolality was not adjusted, it may be that longer exposure compromised the integrity of the sperm membrane and its function.

Ejaculates treated with $2.5 \mathrm{mM}$ NAC showed lower area of the sperm chromatin dispersion compared to untreated sperm. However, they demonstrated similar results to the other treatments. Using the same antioxidant in Mangalarga Marchador semen, this concentration was effective in protecting membrane integrity [9]. Nevertheless, cooling equine semen at $5^{\circ} \mathrm{C}$ to $15^{\circ} \mathrm{C}$, no effect was observed on DNA, motility and membrane function when subjected to NAC concentrations ranging from 1 to $20 \mathrm{mM}$ [23]. This information reinforces the fact that the NAC is able to provide protection when semen is subjected to unfavorable conditions. In our study, using high percentage of seminal plasma under favorable conditions promoted no effect.

NAC $0.5 \mathrm{mM}$ concentration afforded no effect. The $5.0 \mathrm{mM}$ concentration caused DNA damage attributed to the high osmolarity. In addition, no increased
DNA fragmentation of sperm exposed to NAC was observed during cooling despite the high concentrations of sulfur proteins present in the equine plasma. The low molecular weight thiols able to break the bonds of sperm protamines used in DNA chromatin integrity evaluation are 100 times higher than antioxidant doses.

\section{CONCLUSION}

The addition of NAC to pony semen with $50 \%$ seminal plasma does not enhance the appearance of the DNA damage. The concentration of $2.5 \mathrm{mM}$ NAC was able to protect the sperm DNA more than non-supplemented pony semen indicating its use in adverse conditions of sperm survival. Due to the high osmolality triggered by NAC doses of 2.5 and $5.0 \mathrm{mM}$, the results of membrane function was compromised, but motility did not suffer any treatment interference.

\section{MANUFACTURERS}

${ }^{1}$ Sigma Aldrich Co. St. Louis, MO, USA.

${ }^{2}$ Halotech DNA. Madrid, Spain.

Funding. Coordenação de Aperfeiçoamento de Pessoal de Nível Superior - CAPES, Brasília/DF, Brazil and Laboratório de Embriologia Animal - EMBRYOLAB/UFSM, Santa Maria/ RS, Brazil.

Ethical approval. The Ethical and Animal Research Committee from the Federal University of Santa Maria (protocol number 078/2011) approved all procedures involving the pony stallions used in this study.

Declaration of interest. The authors report no conflicts of interest. The authors alone are responsible for the content and writing of the paper.

\section{REFERENCES}

1 Ball B.A. 2008. Oxidative stress, osmotic stress and apoptosis: Impacts on sperm function and preservation in the horse. Animal Reproduction Science. 107: 257-267.

2 Bilodeau J.F., Blanchette S., Gagnon I.C. \& Sirard M.A. 2001. Thiols prevent H2O2-mediated loss of sperm motility in cryopreserved bull semen. Theriogenology. 56: 275-286.

3 Carretero M.I., Lombardo D., Arraztoa C.C., Giuliano S.M., Gambarotta M.C. \& Neild D.M. 2012. Evaluation of DNA fragmentation in llama (Lama glama) sperm using the sperm chromatin dispersion test. Animal Reproduction Science. 131: 63-71.

4 Da Ros V.G., Munuce M.J., Cohen D.J., Marin-Briggiler C.I., Busso D., Visconti P.E. \& Cuasnicu P.S. 2004. Bicarbonate is required for migration of sperm epididymal protein DE (CRISP-1) to the equatorial segment and expression of rat sperm fusion ability. Biology of Reproduction. 70: 1325-1332.

5 David N.R., Lehninger A.L. \& Cox M.M. 2005. Lehninger principles of biochemistry. New York: W.H. Freeman, p.148. 6 Fernández J.L., Muriel L., Rivero M.T., Goyanes V., Vazquez R. \& Alvarez J.G. 2003. The Sperm Chromatin Dispersion Test: A Simple Method for the Determination of Sperm DNA Fragmentation. Journal of Andrology. 24(1): 59-66.

7 Fernández J.L., Muriel L., Goyanes V., Segrelles E., Gonsálvez J., Enciso M., Lafromboise M. \& De Jonge C. 2005. Simple determination of human sperm DNA fragmentation with an improved sperm chromatin dispersion test. Fertility and Sterility. 84(4): 833-842. 
8 Franco J.S.V., Chaveiro A. \& Silva F.M. 2013. Effects of $\alpha$-tocopherol and ascorbic acid on equine semen quality after cryopreservation. Journal of Equine Veterinary Science. 33(10): 787-793

9 Fransico J.A. 2014. Qualidade do Semen Equino Criopreservado com L-Acetil-Cisteína. Dissertação. Universidade Federal de Goias, Escola de Veterinária [Fonte:<https://repositorio.bc.ufg.br/tede/bitstream/tede/4034/2/ Disserta\%C3\%A7\%C3\%A30\%20-\%20Arthur\%20Francisco\%20J\%C3\%BAnior.pdf >]. [Acessed September 2015].

10 Guo M., Teng M., Niu L., Liu Q., Huang Q. \& Hao Q. 2005. Crystal structure of the cysteine-rich secretory protein stecrisp reveals that the cysteine-rich domain has a $\mathrm{K}+$ channel inhibitor-like fold. Journal of Biology Chemical. 280: $12405-12412$.

11 Göetz R. 1949. Besamung und Unfruchtbarkeit der Haussäugetiere. Hannover: Shaper Verlag, 613p.

12 Hughes C.M., Lewis S.E.M., Mckelvey-Martin V.J. \& Thompson W. 1998. The effects of antioxidant supplementation during Percoll preparation on human sperm DNA integrity. Human Reproduction. 13(5): 1240-1247.

13 Jasko D.J., Hathaway J.A., Schaltenbrand V.L., Simper W.D. \& Squires E.L. 1992. Effect of semen plasma and egg yolk on motion characteristics of cooled stallion spermatozoa. Theriogenology. 37: 1241-1252.

14 Katila T. 1997. Procedures for Handling Fresh Stallion Semen. Theriogenology. 48: 1217-1227.

15 Kenney R.M. \& Khaleel S.A. 1975. Bacteriostatic activity of the mare uterus: a progress report on immunology. Journal of Reproduction and Fertility. 23: 357-358.

16 Klug E. \& Sieme H. 2003. Samenübertragung beim Pferd in Theorie und Praxis. $5^{\circ}$ völlig überarbeitete Auflage. Hannover: Verlag M. \& H. Alfeld, 144p.

17 Lagares M.A., Meirelles L.S., Wald V.B., Gregory R.M. \& Mattos R.C. 2000. Efeito de diferentes diluentes sobre a membrana plasmática do espermatozoide equino e fertilidade do sêmen resfriado. Revista Brasileira de Ciência Veterinária. 7(3): 153-156.

18 Love C.C. 2005. The sperm chromatin structure assay: A review of clinical applications. Animal Reproduction Science. 89: 39-45.

19 Michael A.J., Alexopoulos C., Pontiki E.A., Hadjipavlou-Litina D.J., Saratsis P., Ververidis H.N. \& Boscos C.M. 2010. Effect of N-acetyl-L-cysteine supplementation in semen extenders on semen quality and reactive oxygen species of chilled canine spermatozoa. Reproduction in Domestic Animal. 45(2): 201-207.

20 Nichi M. 2009. Efeito do tratamento com antioxidantes e ácidos graxos poli-insaturados em amostras espermáticas e epididimárias de touros. 120f. Tese (Doutorado em Ciências Animais) - Faculdade de Medicina Veterinária e Zootecnia, Universidade de São Paulo, São Paulo. Disponível online: <www.teses.usp.br/teses/disponiveis/10/10131/tde-18012010095928> [Acessed February 15].

21 Neild D.M., Chaves M.G., Flores M., Miragaya M.H., Gonzalez E. \& Agüerro A. 2000. The HOS test and its relationship to fertility in the stallion. Andrologia. 32: 351-355.

22 Pgal R., Aurich C. \& Kankofer M. 2006. Anti-oxidative status and semen quality during cooled storage in stallions. Journal of Veterinary Medicine. 53: 486-489.

23 Reghini M.F.S., Uliani R.C., Monteiro G.A., Dell'aqua Junior J., Papa F.O. \& Alvarenga M.A. 2011. Utilização da $\mathrm{N}$-acetilcisteína na conservação do sêmen eqüino a $5^{\circ} \mathrm{C}$ e $15^{\circ} \mathrm{C}$. In: I Simpósio ABRAVEQ SUL (Gramado, Brazil). http://www.itarget.com.br/newclients/abraveq2012/?p=2353. [Acessed April 2014].

24 Schambony A., Gentzel M., Wolfes H., Raida M., Neumann U.T. \& Opfer-Petersen EA. 1998. Equine crisp-3: primary structure and expression in the male genital tract. Biochimica et Biophysica Acta. 1387: 206-216.

25 Urrego R., Rios A., Ángel M.O. \& Camargo O. 2008. Efecto de la centrifugación sobre la membrana plasmática y el ADN de espermatozoides bovinos. Revista Colombiana de Ciencias Pecuárias. 21(1): 19-26.

26 Varner D.D., Blanchard T.L., Meyers P.J. \& Meyers S.A. 1989. Fertilizing capacity of equine spermatozoa stored for 24 hours at 5 or $20^{\circ} \mathrm{C}$. Theriogenology. 32: 515-525.

27 Whitaker B.D., Casey S.J. \& Taupier R. 2012. N-acetyl-1-cysteine supplementation improves boar spermatozoa characteristics and subsequent fertilization and embryonic development. Reproduction in Domestic Animals. 47(2): 263-268. 